\title{
Analisis Perbedaan Peak Expiratory Flow (PEF) Pada Atlet Olahraga Renang dan Lari
}

\author{
Kukuh Pambuka Putra* , Angkit Kinasih, Ardi Purwa Nugraha
}

\begin{abstract}
Background: Asthma is a chronic disease that can be found in all ages. Basic Health Research Data (RISKESDAS) 2013 shows the prevalence in Indonesia of 4.5\%. Asthma affects the expiratory rate in the lungs. PEF is the maximum expiratory speed that can be achieved by a person, expressed in liters per minute ( $\mathrm{L} / \mathrm{min}$ ) or liters per second ( $\mathrm{L} / \mathrm{sec}$ ). PEF can be measured using PEF meter. PEF meter is a tool for measuring maximum expiratory speed. Aerobic exercise such as swimming and running is the recommended exercise for asthmatics.
\end{abstract}

Objective: This study aims to study the differences in PEF in individuals who regularly exercise swimming and running.

Method: This study is a comparative study. The subjects of this study were 20 athletes who actively sport swimming and 20 athletes who are active in running sport determined by purposive sampling technique. Data analysis using independent $t$ test.

Result: The results of the study using the independent $t$ test sig.0,890 value which states the average value of PEF athletes pool and run the same.

Conclusion: Based on the research the value of PEF athletes pool higher than the value of PEF athletes run

Keyword: Asthma, PEF, Swimming, Running

\section{Intisari}

Latar Belakang: Asma merupakan penyakit kronis yang dapat dijumpai di semua usia. Data Riset Kesehatan Dasar (RISKESDAS) 2013 menunjukan prevalensi di Indonesia sebesar 4,5\%. Penyakit asma berpengaruh terhadap kecepatan ekspirasi pada paru-paru. PEF adalah kecepatan ekspirasi maksimal yang bisa dicapai oleh seseorang, dinyatakan dalam liter per menit (L/menit) atau liter per detik (L/detik). PEF dapat diukur menggunakan PEF meter. PEF meter merupakan alat untuk mengukur kecepatan ekspirasi maksimal. Olahraga yang bersifat aerobik seperti renang dan lari adalah olahraga yang dianjurkan untuk penderita asma.

Tujuan: Penelitian ini bertujuan untuk mempelajari perbedaan PEF pada individu yang rutin melakukan olahraga renang dan lari.

Metode: Penelitian ini merupakan studi komparatif. Subyek penelitian ini adalah 20 atlet yang aktif olahraga renang dan 20 atlet yang aktif olahraga lari yang ditentukan dengan teknik purposive sampling. Analisis data menggunakan uji t independent.

Afiliasi Penulis

Universitas Kristen Satya Wacana

Korespondensi kepada

K.P. Putra

kukuh.pambuka@staff.uksw.edu
Hasil: Hasil penelitian menggunakan uji t independent nilai sig.0,890 yang menyatakan rata-rata nilai PEF atlet renang dan lari sama.

Kesimpulan: Berdasarkan penelitian nilai PEF atlet renang lebih tinggi dibandingkan nilai PEF atlet lari.

Kata kunci: Asma, PEF, Renang, Lari 


\section{Pendahuluan}

Asma adalah suatu kelainan berupa inflamasi (peradangan) kronik saluran nafas yang sering di derita oleh anak-anak, orang dewasa maupun para lanjut usia. Penyakit asma memiliki karakteristik yaitu serangan periodik yang stabil (1). Asma dapat menyebabkan hiperreaktivitas bronkus terhadap berbagai rangsangan yang ditandai dengan gejala episodik berulang berupa batuk, sesak nafas, dan rasa berat di dada. Pada umumnya serangan asma terjadi pada malam hari atau dini hari yang umumnya bersifat reversible (2).

Prevalensi asma menurut WHO (World Health Organization) tahun 2006, jumlah penderita asma di dunia mencapai 235 juta dengan angka kematian lebih dari 80\% di negara-negara berkembang (3). Di Indonesia kasus asma masih tergolong tinggi, berdasarkan hasil RISKESDAS tahun 2013 dilakukan survey terhadap 1.027 .763 responden dan sebanyak 46.250 (4,5\%) responden yang masuk dalam prevalensi asma (4). Persentase kasus asma berdasarkan Profil Kesehatan Jawa Tengah tahun 2015 yaitu sebesar 11,05\% dan dapat meningkat setiap tahunnya (5).

Penelitian Wahyu (2013) (6) menjelaskan bahwa faktor penyebab asma adalah alergen, infeksi saluran nafas, tekanan pikiran, kebiasaan olahraga, obat-obatan, polusi udara dan lingkungan kerja. Faktor risiko asma terdiri dari internal dan faktor eksternal. Faktor internal yaitu genetik, jenis kelamin, usia, dan aktivitas fisik, sedangkan faktor eksternal yaitu infeksi virus di saluran nafas, asap rokok, polusi udara, obatobatan dan perubahan suhu terkait perubahan musim atau kondisi geografis (7). Dampak buruk asma meliputi penurunan kualitas hidup, penurunan produktivitas, peningkatan biaya kesehatan, risiko perawatan di rumah sakit dan bahkan kematian (8).

Pernafasan adalah peristiwa menghirup udara dari luar yang mengandung $\mathrm{O}_{2}$ kedalam tubuh atau paru-paru serta menghembuskan udara yang banyak mengandung $\mathrm{CO}_{2}$ sebagai sisa dari oksidasi ke luar dari tubuh. Pada saat terjadi serangan asma terjadi penyempitan saluran nafas akibat suatu proses peradangan/inflamasi serta pengeluaran mucus/lendir pekat secara berlebihan. Gangguan sumbatan saluran nafas atau fungsi paru dapat diukur secara obyektif dengan variabel PEF (Peak Expiratory Flow). PEF adalah kecepatan ekspirasi maksimal yang bisa dicapai oleh seseorang, dinyatakan dalam liter per menit (L/menit) atau liter per detik (L/detik). PEF dapat diukur menggunakan PEF meter. PEF meter merupakan alat yang dapat digunakan penderita asma untuk mendeteksi dan mengukur jumlah aliran udara sehingga dapat mengidentifikasi adanya obstruksi pernafasan (9). Jika saluran nafas menyempit atau tersumbat karena asma, nilai peak flow akan menurun. Pengukuran PEF memungkinkan penderita asma dapat memonitor kondisi saluran nafas sehari-hari.

Olahraga akan meningkatkan daya tahan dan kekuatan pada otot pernafasan sehingga kemampuan mengembangkan paru-paru akan bertambah (10). Pada penderita asma, otot-otot pernafasan akan mengalami kelemahan, hal ini disebabkan karena sering terjadinya dispnea (sesak). Oleh karena itu otot pernafasan penderita asma perlu dikuatkan dengan olahraga, terutama olahraga kekuatan dan daya tahan (11). Olahraga yang dianjurkan pada penderita asma salah satunya adalah olahraga renang (12). Menurut Septian (2017) olahraga renang terbukti mampu meningkatkan kecepatan ekspirasi maksimal atau PEF bagi penderita asma. Renang memberikan pengaruh positif bagi penderita asma, namun metode latihan renang perlu diperhatikan dengan mempertimbangkan faktor usia dan tingkatan asma (13).

Selain olahraga renang salah satu olahraga yang dianjurkan untuk penderita asma adalah lari atau jogging. Olahraga lari adalah salah satu olahraga yang bertujuan untuk meningkatkan kebugaran fisik, kekuatan otot-otot pernafasan, kepercayaan diri penderita asma dan akan mengurangi ketergantungan penderita asma tersebut terhadap obat-obatan (14). Olahraga lari tidak mengubah ukuran paru-paru tetapi meningkatkan efisiensi otot pernafasan dan memungkinkan penggunaan kapasitas yang lebih besar (15). Namun belum diketahui olahraga mana yang lebih efektif dalam meningkatkan PEF.

Penelitian ini bertujuan untuk membandingkan PEF pada individu yang rutin melakukan olahraga 
Tabel 1 | Instrumen Penggunaan Peak Expiratory Flow (PEF)(16, 17, 18, 19)

No

Langkah-langkah Menjelaskan PEFMeter

1 Menginstruksikan subyek meletakkan peak flow meter dengan tegak.

2 Geser penanda pada peak flow meter ke posisi paling bawah (angka 0)

3 Berdiri. Ambil napas dalam- dalam dan hembuskan hingga udara habis. Jika subjek dalam keadaan cacat fisik, maka subjek harus duduk dengan tegak.

4 Pegang mouthpiece di depan mulut. Ambil napas dalam sebanyak mungkin dengan mulut terbuka. Tempatkan mouthpiece di mulut dan tutup bibir di sekitar peak flow meter agar tersegel. Jauhkan

5 jari dari penanda. Tiup sekali keras dan cepat. (Menginstruksikan subyek untuk tidak mengibaskan kepala ke bawah, karena hal ini akan membuat hasil pembacaan lebih tinggi)

6 Jangan menyentuh penanda dan tuliskan nomor yang Anda dapatkan.

7

Ulangi dua kali lagi. selalu ulang penanda ke nol setiap kali akan melakuannya. Catat nomor setiap

kali setelah penggunan. Angka peak flow adalah yang tertinggi dari pengukuran.

8

Hitung perbandingan nilai terbaik yang pernah dicapai dengan angka yang tertera pada alat tiap kali Pengukuran.

renang dan lari. Diharapkan hasil penelitian ini dapat menjadi referensi bagi penderita asma untuk memilih olahraga yang sesuai sebagai terapi pengobatan asma

\section{Metode}

Penelitian ini merupakan studi komparatif. Penelitian ini akan mempelajari perbedaan PEF pada individu yang rutin melakukan olahraga renang dan lari. Instrumen yang digunakan untuk mengukur PEF adalah PEFmeter. Kriteria inklusi penelitian ini adalah atlet laki-laki yang berusia 1619 tahun, tinggi badan $166-173 \mathrm{~cm}$, berat badan 55-60 kg dan lingkar dada antara 76-81 cm, aktif atau rutin berolahraga renang atau lari minimal 3 kali dalam seminggu dan yang sudah menjalankan aktivitas renang atau lari minimal 3 bulan dan bersedia menjadi subyek penelitian dibuktikan dengan informed consent. Kriteria eksklusi penelitian ini adalah hal-hal lain yang tidak masuk dalam kriteria inklusi. Subyek penelitian sebanyak 40 orang atlet laki-laki yang terbagi menjadi dua kelompok yaitu kelompok yang aktif dalam berenang dan yang aktif dalam lari masing-masing 20 orang. Sampel penelitan ini ditentukan menggunakan teknik purposive sampling yaitu menetapkan sampel berdasarkan kriteria tertentu.

Prosedur pengambilan data yang dilakukan adalah sebagai berikut: sebelum melaksanakan pengukuran PEF, subjek penelitian dikumpulkan dan diberikan penjelasan mengenai maksud penelitian, tujuan penelitian dan prosedur pengukuran PEF yang tertera pada tabel 1. Subjek penelitian kemudian diberikan lembar penjelasan untuk mendapat persetujuan setelah itu mengisi lembar informed consent yang menyatakan bersedia mengikuti pengukuran. Pengukuran antorpometri dilakukan untuk mengetahui tinggi badan, berat badan, lingkar dada dan hal lain seperti umur, berapa lama sudah melakukan olahraga renang dan lari tersebut dan berapa kali latihan dalam seminggu. Setelah itu dilakukan pengukuran PEF dengan percobaan sebanyak $3 x$ dan diambil nilai PEF yang tertinggi. Data yang diperoleh kemudian akan dianalisis menggunakan uji t independen.

\section{Hasil}

Berdasarkan tabel 2, umur subyek penelitian berkisar antara 16-19 tahun, berat badan berkisar antara 55-61 kg. Tinggi badan atlet renang berkisar antara $166-171 \mathrm{~cm}$ dan tinggi badan atlet lari berkisar antara $168-173 \mathrm{~cm}$. lingkar dada berkisar antara $76-80 \mathrm{~cm}$ dan lama latihan atlet renang 1-10 tahun dan atlet lari 1-6 tahun diliat dari lama

\section{Tabel 2 | Data karakteristik responden}

\begin{tabular}{lccccc} 
Atlet & $\begin{array}{c}\text { Umur } \\
(\text { tahun) }\end{array}$ & $\begin{array}{c}\text { BB } \\
(\mathrm{kg})\end{array}$ & $\begin{array}{c}\text { TB } \\
(\mathrm{cm})\end{array}$ & $\begin{array}{c}\text { LD } \\
(\mathrm{cm})\end{array}$ & $\begin{array}{c}\text { Lama Latihan } \\
(\text { tahun) }\end{array}$ \\
\hline Renang & $16-19$ & $55-61$ & $166-171$ & $76-80$ & $1-10$ \\
Lari & $16-19$ & $55-61$ & $168-173$ & $76-80$ & $1-6$
\end{tabular}


Tabel 3 | Nilai PEF Subyek Penelitian

\begin{tabular}{lcccc} 
Atlet & $\mathrm{N}$ & $\begin{array}{c}\text { Tertinggi } \\
(\mathrm{L} / \text { menit })\end{array}$ & $\begin{array}{c}\text { Terendah } \\
(\mathrm{L} / \text { menit })\end{array}$ & Rerata \\
\hline Renang & 20 & 600 & 490 & 547 \\
\hline Lari & 20 & 530 & 410 & 471
\end{tabular}

\begin{tabular}{|c|c|c|}
\hline 560 & 547 & \\
\hline 540 & & \\
\hline 520 & & \\
\hline 500 & & \\
\hline 480 & & 471 \\
\hline 460 & & \\
\hline 440 & & \\
\hline \multirow[t]{2}{*}{420} & & \\
\hline & Renang & lari \\
\hline
\end{tabular}

Gambar 1 | Perbandingan rerata nilai PEF pada atlet renang dan lari

latihan seluruh responden dalam penelitian ini sudah terlatih.

Berdasarkan tabel 3, PEF tertinggi pada atlet renang yaitu $600 \mathrm{~L} /$ menit dan PEF terendah yaitu $490 \mathrm{~L} /$ menit dengan rerata PEF yaitu $547 \mathrm{~L} /$ menit. PEF tertinggi pada atlet lari yaitu $530 \mathrm{~L} /$ menit dan PEF terendah yaitu $410 \mathrm{~L} /$ menit dengan rerata 471 $\mathrm{L} /$ menit. Hasil tersebut menunjukan nilai PEF atlet renang lebih tinggi dibandingkan atlet lari.

Hasil uji normalitas Kolmogorov-Smirnov adalah 0,655 (>0,05). Yang berarti data PEF berdistribusi normal, sehingga dapat dilanjutkan uji $t$ independen.

Berdasarkan tabel 4, hasil uji t independen di dapati $p=0,000(<0,05)$ yang berarti ada perbedaan yang signifikan antara nilai PEF pada kelompok renang dan lari.

\section{Pembahasan}

Berdasarkan tabel 2, umur responden berkisar antara 16-19 tahun. Pemilihan umur tersebut karena rata-rata dengan umur tersebut nilai PEF masih tergolong tinggi. Sejak masa kanak-kanak kapasitas paru-paru bertambah volumenya dan akan mencapai maksimumnya pada usia 19-21 tahun (21). Nilai PEF dapat ditingkatkan dengan melakukan olahraga. namun banyak penderita asma merasa takut untuk melakukan olahraga karena olahraga merupakan salah satu pencetus munculnya serangan asma padahal pada dasarnya olahraga merupakan sarana untuk mengontrol serangan kekambuhan penyakit asma, akan tetapi olahraga tidak dilakukan secara berlebihan harus ada porsi yang cukup untuk melakukannya.

Sampel responden yang dipilih laki-laki karena nilai kapasitas paru-paru laki-laki lebih besar dibandingkan perempuan, itu dikarenakan aktivitas sehari-hari laki-laki lebih banyak dibandingkan perempuan dan perempuan juga memiliki kaliber saluran pernapasan yang lebih kecil dibandingkan dengan laki-laki, laki-laki memiliki kapasitas inspirasi yang lebih besar, dan kekuatan otot lakilaki lebih besar (22). Faktor lainnya besarnya kapasitas paru-paru dipengaruhi oleh faktor umur, berat badan, tinggi badan dan lingkar dada. Lama latihan seseorang juga sangat mempengaruhi dalam hasil PEF. Orang yang sering melakukan aktivitas fisik yang rutin cenderung akan meningkatkan kemampuan otot-otot pernafasan dan orang yang terlatih dengan latihan fisik, jika melakukan kegiatan mempunyai kemampuan

Tabel 4 | Independent Sample T-test

Levene's Test for Equality of Variances t-test for Equality of Means

PEF Atlet

(L/menit)
Equal variances assumed

Equal variances not assumed
Sig

0.19

0.890

$-8.748$

38 df Sig. (2- Mean tailed) Difference

8.748

$-8.748$

37.966

.000

$-75.750$ 
untuk menghisap udara lebih banyak dan dalam periode waktu yang lebih lama, juga mampu menghembuskan keluar sisa-sisa pembakaran lebih banyak, sebab otot-otot di sekeliling paru-parunya telah terlatih untuk melakukan kerja lebih banyak (23). Pendapat tersebut juga didukung oleh penelitian dari Naftalione, 2018 yang mengatakan orang yang melakukan aktivitas fisik secara rutin dan teratur akan memiliki nilai PEF yang lebih tinggi dibandingkan dengan orang yang tidak melakukan aktifitas fisik apapun (24).

Berkurangnya aktivitas fisik dapat menjadi salah satu faktor meningkatnya prevalensi terjadinya asma. Salah satu indikasi adanya penyumbatan pada saluran pernafasan adalah rendahnya nilai PEF atau disebut juga PEFR (Peak Expiratory Flow Rate) yaitu kecepatan hembusan maksimum yang diukur pada 10 milidetik pertama ekspirasi (25). Peningkatan nilai PEF pada asma menunjukkan penurunan penyumbatan pada saluran nafas dimana perbaikan saluran nafas dapat mencegah terjadinya kekambuhan yang ditandai dengan berbagai gejala asma, terjadinya peningkatan nilai PEF dan penurunan frekuensi kekambuhan asma merupakan indikasi ringan atau beratnya derajat asma seseorang. Latihan renang dan lari sangat membantu untuk mengurangi kekambuhan asma, karena dengan aktivitas fisik berupa lari dan renang dapat melatih seluruh otot pernafasan yang mampu memperbaiki kondisi pasien asma. Berdasarkan tabel 2 atlet renang memiliki nilai rerata yang lebih besar dari pada atlet lari. Sesuai dengan pendapat Tortora (2009) yang mengatakan bahwa latihan renang dapat meningkatkan diameter, jumlah mitokondria, suplai darah dan kekuatan otot pada sistem pernapasan karena latihan renang merupakan salah satu jenis olaraga aerobik yang dapat merubah serabut otot sehingga dapat menyebabkan perubahan pada beberapa serabut "fast glycolytic/FG fiber" menjadi "fast oxidative-glycolytic/FOG fiber hal tersebut yang membuat peningkatan terhadap hasil PEF. Latihan renang lebih banyak membutuhkan energi dibandingkan dengan latihan lain (lari atau berjalan) karena latihan renang lebih menekankan pada gerakan kaki dan lengan serta ada kekuatan yang merintangi subyek, yaitu air sehingga fungsi pulmonal pada otot-otot pernapasan juga lebih baik (26). Menurut Wijaya, (2015) olahraga renang dapat dilakukan untuk penyembuhan asma dengan dilakukan 3-4 kali dalam seminggu dilakukan dalam durasi 15-60 menit setiap sesi dan sebaiknya dimulai dengan pemanasan terlebih dahulu (14).

Hasil analisis uji normalitas pada penelitian menunjukkan bahwa nilai $p>0,05$ sehingga dapat diambil kesimpulan bahwa distribusi rerata nilai PEF pada atlet renang dan lari berdisribusi normal, sehingga uji tersebut dapat dilakukan (27). Uji t independen dilakukan untuk mengetahui perbedaan signifikan antara PEF atlet renang dan atlet lari dan didapatkan nilai $p<0,05$. Maka ditarik kesimpulan hasil analisis uji $\mathrm{t}$ independent bahwa terdapat perbedaan yang bermakna antara ratarata nilai PEF pada atlet renang dan atlet lari.

\section{Kesimpulan}

Latihan renang dan lari dapat meningkatkan nilai Peak Expiratory Flow (PEF). Berdasarkan penelitian nilai PEF atlet renang dan atlet lari terdapat perbedaan yang signifikan. Nilai PEF tertinggi terdapat pada pengukuran nilai PEF atlet renang. Tingginya nilai PEF tersebut menunjukkan bahwa latihan olahraga renang dapat digunakan sebagai olahraga yang baik bagi penderita asma.

Dalam penelitian ini terdapat beberapa keterbatasan yang tidak memungkinkan dilakukan menggunakan jumlah sampel yang besar berdasarkan kriteria inklusi dan eksklusi. mungkin penelitian lebih lanjut perlu dilakukan pengukuran PEF pada cabang olahraga lain seperti olahraga jalan cepat, sepeda, olahraga raket dan senam.

\section{Bibliografi}

1. Sykes, and Johnston, 2008. Etiology of Asthma Exacerbations. Online

2. Direktorat Pengendalian Penyakit Tidak Menular. 2009. Pedoman Pengendalian Penyakit Asma. p. 10.

3. World Health Organization. 2008. Asthma Fact Sheets: WHO Library Cataloguin-in-publication Data. HIm. 57

4. Badan Penelitian dan Pengembangan Kesehatan. 2013. Riset Kesehatan Dasar (RISKESDAS) 2013. Lap Nas 2013. 2013;1-384.

5. Dinkes, Jateng. 2015. Profil Kesehatan Jawa Tengah tahun 2015, Semarang: Dines Jateng 
6. Wahyu C, Pepin N, Hexawan T. 2013. Analisa FaktorFaktor Pencetus Derajat Serangan Asma Pada Penderita Asma Di Puskesmas Perak Kabupaten Jombang Tahun 2013 ( Analysis Trigger Factors Degrees Asthma Attack on Public Health Center Perak Jombang District Year 2013).

7. Suyono, S., 2001. Buku Ajar IImu Penyakit Dalam, Jilid 2, Edisi 3. Jakarta : Balai Penerbit FK - UI, hlm. 21, 22, 23, 27,28, 29, 31, 33, 41.

8. Klinik Dbfkd. Pharmaceutical care. 2006. Direktorat Bina Farm Komunitas Dan Klin Ditjen Bina Kefarmasian Dan Alat Kesehatan. Dep Kesehat 2006.;1-73.

9. Naca Naca. Asthma \& Lung Function Tests. 2012;6.

10. Guyton AC HJ. 2006. Buku Ajar Fisiologi Kedokteran. Jakarta: penerbit buku kedoteran EGC;

11. Yunus, F., Adriskanda, B., Setiawan, B. 2007. Perbandingan Nilai Kapasitas Difusi Paru antara Orang yang Terlatih dan Tidak Terlatih. Jurnal Respirologi Indonesia;.2 (3). 17, 76, 83.

12. Weiner $P$, Magadle R, Beckerman M, Weiner M, BerarYanay N. Comparison of Specific Expiratory, Inspiratory, and Combined Muscle Training Programs in COPD. Chest. 2003;124(4):1357-64. 8. Robert E. Remember: it is your responsibility to keep the ASA informed. :1-3.

13. Septian. 2017. Metode terapi renang drill selama 4 minggu bagi penderita asma dan pengaruh terhadap peak Expiratory Flow (PEF). Universitas Kristen Satya Wacana. salatiga;.

14. Wijaya MK. 2015. Aktivitas Fisik (Olahraga Pada Penderita Asma. Proccedings Seminar Nasional FMIPA UNDIKSHA V Tahun 2015; p.336-41.

15. Sharkey, J., Brian. 2003. Kebugaran Kesehatan. Grafindo. Jakarta.

16. CQI Projects Vol. 1 - 2002. Healthcare management. The Ministry of Health, Kingdom of Bahrain.

17. Peak Flow Meter Patient Education Handout associated with UMHS Clinical Care Guideline, University of Michigan Health System, 2010.

18. Asthma Education Clinic. How to Use a Peak Flow Meter. BC Children's Hospital. 2011.

19. Pongdee T. Peak Flow Meter. American Academy of Allergy, Asthma \& Immunology (AAAAI). 2013.

20. Santoso Singgih, 2015. SPSS 20. Jakarta: Gramedia.

21. Widi Atmoko. 2011. Prevalens Asma Tidak Terkontrol dan Faktor-Faktor yang Berhubungan dengan Tingkat Kontrol Asma di Poliklinik Asma Rumah Sakit Persahabatan, Jakarta. J Respir Indo Vol. 31, No. 2, April 2011.
22. Manfreda J, Sears MR, Becklake MR, ChanYeung 21 . M, Dimich-Ward H, Siersted HC. 2004. Geographic and gendervariability in the prevalence of bronchil responsiveness in Canada. Chest 2004; 125: 1657-64.

23. Cooper Kenneth H. 1983. Aerobik.Cetakan kelima.PT. Gramedia. Jakarta.

24. Naftalione. 2018 .Hubungan Aktivitas Fisik dan Obesitas terhadap Peak Expiratory Flow pada Siswa SMAN 1 Candiroto Temanggung Jawa Tengah. Universitas Kristen Satya Wacana; Salatiga.

25. Proverawati, A., \& Widianti, A.T. 2010. Senam kesehatan. Yogyakarta : Nuha Medika.

26. Tortora G.J., Derricson B.H. 2009. Principles of Anatomy and Physiology.1frs.ed. 12. New York: John Wiley and Sons Inc.

27. Dahlan, S. 2015. Statistik untuk Kedokteran dan Kesehatan. Jakarta: Epidemiologi Indonesia. 